\title{
Tax Avoidance: A Study of Non-Financial Companies Listed in Indonesia Stock Exchange
}

\author{
Liany Sumaha Indah ${ }^{1}$, Novia Wijaya ${ }^{1 *}$ \\ ${ }^{1}$ Trisakti School of Management, Jalan Kyai Tapa No. 20, 1140, Jakarta, Indonesia \\ "Corresponding author. Email: novia@stietrisakti.ac.id
}

\begin{abstract}
Since tax is our country's main source of financing, in Indonesia we conduct the calculation, payment, and reporting of the tax by using the self-assessment method. We know that this will be the opportunity for some companies to not report the tax they owe correctly and honestly. The fundamental purpose of this study was to obtain an empirical evidence about some factors which will affect the tax avoidance. This study selected seven variables to be used, which are firm size, return-on-asset, leverage, capital intensity, sales growth, the composition of independent commissioner, and executive compensation. The population in this study is nonfinancial companies listed in the Indonesia Stock Exchange (IDX) over the past four years 2015-2018. This study used 255 sample data that are selected by using the purposive sampling method. The hypotheses in this research were analyzed by using multiple linear regression. The results of this study indicate that return-onasset and sales growth have an influence on tax avoidance, while other independent variables such as firm size, leverage, capital intensity, the composition of independent commissioner, and executive compensation do not influence tax avoidance.
\end{abstract}

Keywords: Tax Avoidance, Leverage, Capital Intensity, Return-on-Asset, Sales Growth, The Composition of Independent Commissioner, Executive Compensation

\section{INTRODUCTION}

Tax is the obligatory arrears owed to a country by personal / corporate instances, and then is used by the country for its people well-being. We know that in 1980 s, there was a Tax Reformation indicating that tax is our country main source of financing. It also can be seen as one of the main functions of tax which is as a budgetary function. We know that by 2018, tax income was dominating our country's income, as much as $1.315,93$ trillion. However, that number was still minus 109 trillion from 2018 State Budget [1]. It indicated that there are still so many taxpayers who don't conduct their responsibility correctly and honestly. Management in the corporations want to pay the taxes as low as possible using loophole from the tax laws and regulations. Besides, our country is depending on tax as its own source of financing. The interest differences between management and the country makes the government should tighten their process / system in order to collect that taxes from its people [2].

Tax avoidance is more preferred by the management, because it's not against the tax laws and regulations, so it can push the tax at the lowest point without getting penalized. Tax avoidance is used by utilizing the loopholes from the tax laws and regulations. Thus, the management can be efficient in paying the taxes that are owed [3]. In another way, tax evasion is illegal and also unethical, because it entails deception and concealment. Tax avoidance is more like rational business planning that takes advantage on a legal loophole [4].

This study is a replication of [2] entitled: Faktor-Faktor yang Mempengaruhi Penghindaran Pajak pada Perusahaan Manufaktur di Bursa Efek Indonesia, which was further developed by: (1) Adding a new dependent variable: executive compensation from [13]; (2) Renew the study's period to 2016-2018; and (3) Change the object of the study to non-financial companies.

This study's objective was to obtain empirical evidence about the effect of firm size, return-on-asset, leverage, capital intensity, sales growth, the composition of independent commissioner, and executive compensation on tax avoidance.

The contribution that we expected are: (1) To become a source of literature that can help the other academics as a reference for their study; (2) Increase the people's knowledge about the factors that affect tax avoidance; and (3) For government to be fairer and more transparent about their regulations, so there isn't any misperception occur.

\section{THEORETICAL FRAMEWORK AND HYPOTHESIS DEVELOPMENTS}

\subsection{Agency Theory}

This theory was developed when the America's capital market was developing in 1976. As the capital market developing, it's clear that there is the role of separation 
between the capital's owners and management. This separation raises the information gap, because the company I management side has more information about the company's operation. The main trigger is that there's an interest difference between the owners (principal) and the management (agency)

In this case, the principal is the country's government, that have already tried to limit the gap by giving incentives [5], for example, there is a change in the corporate tax-rate from $28 \%$ to $25 \%$ by 2010 , also with the tax income relief [6]. In Indonesia, the calculation, payment, and reporting of tax are done by using the self-assessment method, which means that the company should conduct that process independently. A company also has a different interest, that is to pay the taxes as low as possible, so the distribution of the company's net income to management and owners can be higher. The government also don't know if the tax payment reported by the company is genuine or not.

\subsection{Tax Avoidance}

According to Dyreng et al. (2008) in [3], tax avoidance is an activity that affects the tax responsibility, including the activity that is particularly designed to deduct the tax owed, also if this activity is basically allowed by the tax laws and regulations. As confirmed by Sari (2014) in [7], tax avoidance being used are loopholes or the infirmity from such laws and regulations. Tax avoidance is the result of measures taken to minimize the tax and, while in keeping with the letter of the law, are contrary to the purpose and spirit of the law. When these arrangements are done to keep with the spirit of the law, it can be defined as an effective tax planning [8].

\subsection{Firm Size}

Firm size is the scale that shows how big or small the company is based on its total asset, average total asset, total revenue, and average total revenue [2]. The maturity of a company is shown by the amount of total asset, which indirectly means as a great prospect for the company's sustainability [7]. Based on the literature review, the relationship between tax avoidance and firm size is hypothesized as $\mathrm{H}_{1}$ : There is a positive relationship between firm size and tax avoidance.

\subsection{Return-on-Asset}

Return-on-Asset (ROA) is used to measure the effectiveness of a company to utilize its resources. The higher ROA means that the company has a great financing performance [2]. This performance is shown by the ability to utilize the assets in order to gain net income [7]. Darmadi (2013) in [7] also said that for a company with high efficiency, its tax expenses can be as low as they want. ROA is used to measure the profitability. [9] said that, ROA allows us to measure a return or reward that a company gives to its stockholders and creditors. This reward is given based on net income that the company generates. Thus, this net income becomes the basis for tax calculation. Based on the literature review, the relationship between tax avoidance and return-on-asset is hypothesized as $\mathrm{H}_{2}$ : There is a positive relationship between return-on-asset and tax avoidance.

\subsection{Leverage}

Leverage is the ratio to measure how far the financing for the company's investment comes from debt. When the company owes, it should pay the interest expense that occurs. Interest expense is one of the deductible components of taxable income [2]. Big companies often use the capital from what they have rather than borrow from external parties, and the government also becomes more interested with them. Regarding the tax law number 36 / 2008 , it regulates about the criteria for deductible interest expense, which is the interest expense from external unrelated party's borrowing. According to [10], a company that tends to have borrowing, has more effective tax-rate than others that do not. Based on the literature review, the relationship between tax avoidance and leverage is hypothesized as $\mathrm{H}_{3}$ : There is a positive relationship between leverage and tax avoidance.

\subsection{Capital Intensity}

Capital intensity shows how much capital needed by a company to generate the income from an increase and decrease of fixed assets. Depreciation is the counterpart of fixed assets, and also the deductible component. If there is more expense in the company, then the net income should be lower, which lower the taxes to be paid by the company [2]. In accordance with the agency theory, management wants to have more compensation by increasing the company's performance. Management would try to utilize the depreciation expenses that is embodied in fixed assets to decrease the tax expenses. Management would always try to allocate the idle fund to acquire fixed assets, so the depreciation expenses can also be increased [6]. Based on the literature review, the relationship between tax avoidance and capital intensity is hypothesized as $\mathrm{H}_{4}$ : There is a positive relationship between capital intensity and tax avoidance.

\subsection{Sales Growth}

Sales growth is one of the company's growth indicators other than assets and stock prices. If the amount is high, it means that the company is growing rapidly and the net income generated also has the same meaning. As discussed before, the increase of net income also increases the tax expenses because it is affecting the taxable income [2]. Based on the literature review, the relationship between tax avoidance and sales growth is hypothesized as $\mathrm{H}_{5}$ : There is a positive relationship between sales growth and tax avoidance. 


\subsection{The Composition of Independent Commissioner}

The composition of independent commissioner is a percentage that shows the comparison between the amount of independent commissioner with the total amount of all commissioner [2]. According to Kurniasih and Sari (2013) in [2], the independent commissioners help the financial statement to be more objective, because they perform the monitoring function they have. Independent commissioners monitor and control the director's regulations that are considered could be harmful for the company's future, including the tax avoidance itself [11]. The increased amount of independent commissioner enables them to better monitor the executives, which should mitigate the agency issues and opportunistic tax avoidance that support the best interest for both parties [12]. Based on the literature review, the relationship between tax avoidance and the composition of independent commissioner is hypothesized as $\mathrm{H}_{6}$ : There is a positive relationship between the composition of independent commissioner and tax avoidance.

\subsection{Executive Compensation}

Truthfully, there is no taxpayers who want to voluntarily paid their taxes, because they think that it is not prospering them. The executive, which is the operational leader, would readily conduct the tax avoidance regulation, if they can get something from it. That's why, the efforts that the company do to avoid the taxes can be seen from the higher compensation received by the executive [13]. Executive compensation has two opposing effects on tax avoidance: (1) Encourages manager to engage in tax avoidance activity that generate a sufficient increase in firm value (the incentive-alignment effect); and (2) May reduce the corporate tax avoidance as large equity incentives which will discourage the manager from taking risky tax avoidance strategies (the risk-reducing effect). These two opposing effects may help explain why prior research found mixed evidence on the relationship between the executive compensation and tax avoidance [14]. Based on the literature review, the relationship between tax avoidance and executive compensation is hypothesized as $\mathrm{H}_{7}$ : There is a positive relationship between executive compensation and tax avoidance.

\section{RESEARCH METHOD}

This study could declare the effect of independent variables on the dependent variable. Independent variable is a variable that could affect the dependent variable, although it could be a positive or negative effect. Dependent variable is a variable that could have been affected by the independent variable, which is why this study is looking for [15]. The independent variables in this study are firm size, return-on-asset, leverage, capital intensity, sales growth, the composition of independent commissioner, and executive compensation, while the dependent variable is tax avoidance. The object used in this study as the population is the non-financial companies listed in Indonesia Stock Exchange (IDX) in the period of 2016-2018. The technique used for selecting the samples in this study is the purposive sampling, as part of the non-probability sampling techniques.

\subsection{Operational Definition of Variables and Measurements}

Tax avoidance is all the effort that is done to deduct or omit the tax payable that should be paid by the company, with a way that doesn't break the existing tax laws and regulations. CETR is cash outflow which the company uses to pay the tax divided by net income before tax [2]. The amount used under 1 means that the company does the tax avoidance, because the taxes that should be paid are not all paid by the company. The scale used is the ratio-scale, which can be measured as follow:

$$
\text { CETR }=\frac{\text { Tax Paid }}{\text { Net Income Before Tax }}
$$

The firm size shows how big or small the company is, which can be measured with the asset that the company has. It can be shown by the natural logarithm of the total asset, because this formula is more stable than the other proxies [2]. The scale used is the ratio-scale, which can be measure as follow:

$$
\text { Firm Size }=\text { Natural Logarithm }(\text { Total Asset })
$$

Return-on-Asset is the comparison between net income with the total asset at the end of the period used [2]. The high ROA means that the company is great at generating the net income. The scale used is the ratio-scale, which can be measured as follow:

$$
\mathrm{ROA}=\frac{\text { Net Income After Tax }}{\text { Total Asset }} \times 100 \%
$$

Leverage is the financial ratio used to find out how much the financing of the company's investment comes from debt. Leverage is proxied with the debt-to-equity ratio (DER). DER itself is a comparison between total debt and total equity, of which those two are the sources of financing that the company has [2]. The scale used is the ratio-scale, can be measured as follow:

$$
\text { DER }=\frac{\text { Total Debt }}{\text { Total Equity }}
$$

Capital intensity shows how much capital is needed by the company for generating the income. The prospect of the company can be shown from the capital intensity the company has, because it supports the company to take the opportunity in the market. It can be proxied by dividing fixed asset with total asset that the company has [2]. The scale used is the ratio-scale, which can be measured as follow:

$$
\text { Capital Intensity }=\frac{\text { Total Fixed Asset }}{\text { Total Asset }}
$$


Sales growth is the growth of the company's sales every year. The scale used is the ratio-scale, which can be measured as follow:

Sales Growth $=\frac{\text { Sales End of The Period }- \text { Sales Beginning of The Period }}{\text { Sales Beginning of the Period }}$

The composition of independent commissioner is the member of commissioner that does not affiliate with the management, so they are not considered as the management's interest. The scale used is the ratio-scale, which can be measured as follow:

$\begin{aligned} \text { Composition of Independent Commissioner }= & \frac{\text { Total Independent Commissioner }}{\text { Total Commissioner }} \\ & \times 100 \%\end{aligned}$

Executive Compensation is the compensation in form of cash that the company gives to the executives for a year [13]. Based on [16], executive compensation is referred to the compensation for top executives (top management). The scale used is the nominal-scale, which can be measured as follow:

Executive Compensation $=$ Total Executive Compensation

\section{ANALYSIS AND DISCUSSION}

The result of data analysis shows that there are 85 companies that can be used as the object of this study based on the criteria that have been determined before. These criteria can be seen in Table 1 as follows:

\section{Table 1 Sample Selection Procedure}

\begin{tabular}{|c|c|c|}
\hline Criteria Description & Total Firm & Total Data \\
\hline $\begin{array}{l}\text { Non-financial companies listed in IDX } \\
\text { during 2015-2018 }\end{array}$ & 423 & 1269 \\
\hline $\begin{array}{l}\text { Non-financial companies that do not } \\
\text { present their financial statements and } \\
\text { annual reports during } 2015-2018\end{array}$ & 9 & 27 \\
\hline $\begin{array}{l}\text { Non-financial companies that do not use } \\
\text { IDR currency in their financial } \\
\text { statements during } 2015-2018\end{array}$ & 76 & 228 \\
\hline $\begin{array}{l}\text { Non-financial companies that do not } \\
\text { publish their financial statements as of } \\
\text { December } 31^{\text {st }} \text { during } 2015-2018\end{array}$ & 8 & 24 \\
\hline $\begin{array}{l}\text { Non-financial companies that have } \\
\text { negative net income before-tax during } \\
2016-2018\end{array}$ & 126 & 378 \\
\hline $\begin{array}{l}\text { Non-financial companies that do not } \\
\text { present the components needed for } \\
\text { calculating the variables during } 2016 \text { - } \\
2018\end{array}$ & 86 & 258 \\
\hline $\begin{array}{l}\text { Non-financial companies that do not } \\
\text { have CETR amounted under } 1 \text { during } \\
2016-2018\end{array}$ & 33 & 99 \\
\hline Total Sample & 85 & 255 \\
\hline
\end{tabular}

Source: Data Analysis Results (2020)
Table 2 t-Test Results

\begin{tabular}{|l|c|c|c|}
\hline \multicolumn{1}{|c|}{ Variable } & B & Sig. & Decision \\
\hline Constant & 0.197 & 0.570 & \\
\hline SIZE & 0.006 & 0.646 & $\mathrm{H}_{1}$ was not accepted \\
\hline ROA & -0.006 & 0.007 & $\mathrm{H}_{2}$ was not accepted \\
\hline DER & 0.016 & 0.122 & $\mathrm{H}_{3}$ was not accepted \\
\hline CAPINT & 0.007 & 0.896 & $\mathrm{H}_{4}$ was not accepted \\
\hline SG & -0.100 & 0.048 & $\mathrm{H}_{5}$ was not accepted \\
\hline KOM & -0.001 & 0.306 & $\mathrm{H}_{6}$ was not accepted \\
\hline KOMPEK & $4.136 \mathrm{E}-13$ & 0.580 & $\mathrm{H}_{7}$ was not accepted \\
\hline
\end{tabular}

Source: Data Analysis Results (2020)

The significance level of firm size is 0.646 (greater than $0.05)$ which concludes that $\mathrm{H}_{1}$ could not be accepted. This means that firm size does not influence tax avoidance. The significance level of Return-on-Asset is 0.007 (less than 0.05) which concludes that $\mathrm{H}_{2}$ was not accepted, because it influences tax avoidance but in a negative direction. A negative coefficient means that ROA has a negative influence on CETR proxy, in which the greater the amount of ROA is, the lower the CETR amount will be. This can be indirectly concluded that the tax avoidance is greater.

The efficiency of the company in running its operation can be reflected indirectly by the increase of the company's revenue, which also affects the taxable income base. Due to the more efficient operations, the company would optimize its tax planning more wisely in order to prevent the increase in net income. Otherwise, it should pay the greater amount of tax.

The significance level of leverage is 0.122 (higher than 0.05 ) which concludes that $\mathrm{H}_{3}$ could not be accepted. This means leverage does not influence tax avoidance.

The significance level of capital intensity is 0.896 (greater than 0.05 ) which concludes that $\mathrm{H}_{4}$ could not be accepted. This means that capital intensity does not influence tax avoidance.

The significance level of sales growth is 0.048 (less than 0.05 ) which concludes that $\mathrm{H}_{5}$ was not accepted, because it influences tax avoidance but in a negative direction. A negative coefficient means that sales growth has a negative influence on CETR proxy, in which the greater amount of sales growth is, the lower the CETR amount will be. This can be indirectly concluded that the tax avoidance is greater. The growth of sales shows that the net income of the company will be increased and also the responsibility to pay the tax is increased as well. That's why the management tries to make the tax planning better, so the company will have a stable net income.

The significance level of the independent commissioner composition is 0.306 (higher than 0.05) which concludes that $\mathrm{H}_{6}$ could not be accepted. This means that the 
composition of independent commissioner does not influence tax avoidance.

The significance level of executive compensation is 0.580 (greater than 0.05 ) which concludes that $\mathrm{H}_{7}$ could not be accepted. This means that executive compensation does not influence tax avoidance.

\section{CONCLUSIONS, LIMITATIONS, AND RECOMMENDATIONS}

This study shows that return-on-asset and sales growth has a negative influence on tax avoidance, while firm size, leverage, capital intensity, the composition of independent commissioner, and executive compensation have no influence on tax avoidance. This study has some limitations: (1) The residual data is not normally distributed; (2) Heteroscedasticity problem occur in firm size, return-onasset, and capital intensity; and (3) The limitation of independent variables. The recommendations that researchers can provide are: (1) Adding more data by stretching the research period to 4 years; (2) Transforming the data into logarithm or natural logarithm or another proxy; and (3) Adding some more independent variables, for example, the CSR and executive risk preferences.

Recommendation for the regulators: Make a regulation that is clear and transparent for people and socialize more about the new tax regulations and laws.

Recommendation for the companies that have performed the tax avoidance: Remember that our country's main source of financing for the infrastructure and other public places is the tax income. Tax avoidance is allowed, but don't do it aggressively, because it will harmful for our national developments.

\section{REFERENCES}

[1] Kusuma, Hendra. Penerimaan Pajak Kurang Rp 109 Triliun di 2018. detikFinance, (https://finance. detik.com/berita-ekonomi-bisnis/d4368566/penerimaan -pajak-kurang-rp-109-triliun-di-2018) (2019)

[2] Puspita, Deanna dan Meiriska Febrianti. FaktorFaktor yang Mempengaruhi Penghindaran Pajak Pada Perusahaan Manufaktur di Bursa Efek Indonesia. Jurnal Bisnis dan Akuntansi, Vol. 19, No. 1: 38-46 (2017)

[3] Kartana, I Wayan dan Ni Gusti Agung Sri Wulandari. Pengaruh Karakter Eksekutif, Karakteristik Perusahaan, dan Corporate Governance Terhadap Tax Avoidance. Jurnal Krisna: Kumpulan Riset Akuntansi, Vol. 10, No. 1: 1-13 (2018)

[4] Oats, Lynne and Penelope Tuck. Corporate tax avoidance: is tax transparency the solution? Accounting and Business Research, Vol. 49, No. 5: 565-583 (2019)

[5] Jensen, Michael C. and William H. Meckling. Theory of The Firm: Managerial Behavior, Agency Costs, and Ownership Structure. Journal of Financial Economics 3, 305-360 (1976)
[6] Wiguna, I Putu Putra dan I Ketut Jati. Pengaruh Corporate Social Responsibility, Preferensi Risiko Eksekutif, dan Capital Intensity Pada Penghindaran Pajak. E-Jurnal Akuntansi Universitas Udayana, Vol. 21, No. 1: 418-446 (2017)

[7] Handayani, Rini. Pengaruh Return on Asset (ROA), Leverage, dan Ukuran Perusahaan Terhadap Tax Avoidance Pada Perusahaan Perbankan yang Listing di BEI Periode Tahun 2012-2015. Jurnal Akuntansi Maranatha, Vol. 10, No. 1: 72-84 (2018)

[8] Salhi, Bassem, Jabr Al Jabr, and Anis Jarboui. A Comparison of Corporate Governance and Tax Avoidance of UK and Japanese Firms. Comparative Economic Research. Central and Eastern Europe, Vol. 23, No. 3: 112-132 (2020)

[9] Subramanyam, K. R. Financial Statement Analysis, Eleventh Edition. New York: McGraw-Hill Education (2014)

[10] Dewinta, Ida Ayu Rosa dan Putu Ery Setiawan. Pengaruh Ukuran Perusahaan, Umur Perusahaan, Profitabilitas, Leverage, dan Pertumbuhan Penjualan Terhadap Tax Avoidance. E-Jurnal Akuntansi Universitas Udayana, Vol. 14, No. 3: 1584-1613 (2016)

[11] Putriningsih, Dewi, Eko Suyono, dan Eliada Herwiyanti. Profitabilitas, Leverage, Komposisi Dewan Komisaris, Komite Audit, dan Kompensasi Rugi Fiskal Terhadap Penghindaran Pajak pada Perusahaan Perbankan. Jurnal Bisnis dan Akuntansi, Vol. 20, No. 2: 77-92 (2018)

[12] Li, Qingyuan, Edward L. Maydew, Richard H. Willis, and $\mathrm{Li} \mathrm{Xu}$. Taxes, Director Independence, and Firm Value: Evidence from Board Reforms Worldwide. Research Gate (2016)

[13] Hanafi, Umi dan Puji Harto. Analisis Pengaruh Kompensasi Eksekutif, Kepemilikan Saham Eksekutif, dan Preferensi Risiko Eksekutif Terhadap Penghindaran Pajak Perusahaan. Diponogoro Journal of Accounting, Vol. 3, No. 2: 1-11 (2014)

[14] Chee, Seungmin, Choi Wooseok, and Shin Jae Eun. The Non-Linear Relationship Between CEO Compensation Incentives and Corporate Tax Avoidance. The Journal of Applied Business Research, Vol. 33, No. 3: 439-450 (2017)

[15] Sekaran, Uma and Roger Bougie. Research Methods for Business. United Kingdom: John Wiley \& Sons (2016)

[16] Amstrong, Christopher S., Jennifer L. Blouin, and David F. Larcker. The Incentives for Tax Planning. Journal of Accounting and Economics, S3 (1-2), 391411 (2012) 